\title{
Octanoic Hydrazide-Linked Chitooligosaccharides-2,5-Anhydro-D-Mannofuranose
}

\author{
Amani Moussa and Stéphane Trombotto * \\ Ingénierie des Matériaux Polymères (IMP, UMR CNRS 5223), Université Claude Bernard Lyon 1, Univ Lyon, \\ Campus LyonTech-La Doua, bâtiment Polytech, 15 bd Latarjet, Villeurbanne F-69622, France; \\ amani_moussa24@hotmail.com \\ * Correspondence: stephane.trombotto@univ-lyon1.fr; Tel.: +33-472-431-210
}

Academic Editor: Norbert Haider

Received: 5 July 2016; Accepted: 25 July 2016; Published: 16 August 2016

\begin{abstract}
Chitooligosaccharide with one 2,5-anhydro-D-mannofuranose unit at the reducing end (COSamf) was prepared by nitrous acid depolymerization of chitosan. The reducing-end functionalization of COSamf by reductive amination with octanoic hydrazide in the presence of $\mathrm{NaBH}_{3} \mathrm{CN}$ was achieved in high yield. The chemical structure of the targeted octanoic hydrazide-linked COSamf was fully characterized by NMR spectroscopy and MALDI-TOF mass spectrometry. This synthesis opens the way to a new generation of COSamf derivatives with potential amphiphilic properties.
\end{abstract}

Keywords: chitosan; chitooligosaccharide-2,5-anhydro-D-mannofuranose; octanoic hydrazide; nitrous acid depolymerization; reductive amination, amphiphilic oligomer

\section{Introduction}

Chitosan is a linear copolymer of $\beta$ - $(1 \rightarrow 4)$-linked D-glucosamine $(\mathrm{GlcN})$ and $N$-acetyl D-glucosamine (GlcNAc) units in various proportions. Although present to a low extent in biomass, chitosan is generally obtained by chemical or enzymatic $N$-deacetylation of chitin, the second most abundant naturally occurring polymer produced industrially from shells of crustaceans and squid pens [1-4]. Chitin and chitosan oligomers, also named chitooligosaccharides (COS), have recently received considerable attention as functional biomolecules with a wide range of potential applications in food, agriculture, medicine, pharmaceutics and cosmetics $[5,6]$. COS take advantage of their various interesting physico-chemical and biological properties, including principally water-solubility, biocompatibility, and antibacterial, antiviral and antifungal activities [7-10]. In order to develop new high-potential COS-based materials with advanced and significant value-added applications, the chemical modification of COS is currently being explored intensively [11-15]. In this study, we described the original synthesis of octanoic hydrazide-linked chitooligosaccharide-2,5-anhydro-D-mannofuranose. The interest of this work is to take advantage of the reactivity of the "non-masked" aldehyde group of the 2,5-anhydro-D-mannofuranose (amf) unit present at the reducing end of COS produced by the nitrous acid depolymerization of chitosan. It should open opportunities for preparing numerous COS-based functional materials with amphiphilic properties.

\section{Results and Discussion}

Octanoic hydrazide-linked chitooligosaccharide-2,5-anhydro-D-mannofuranose was efficiently synthesized from chitosan in a two-step procedure involving the reductive amination of chitooligosaccharide-2,5-anhydro-D-mannofuranose (COSamf 1) with octanoic hydrazide as illustrated in Scheme 1. 

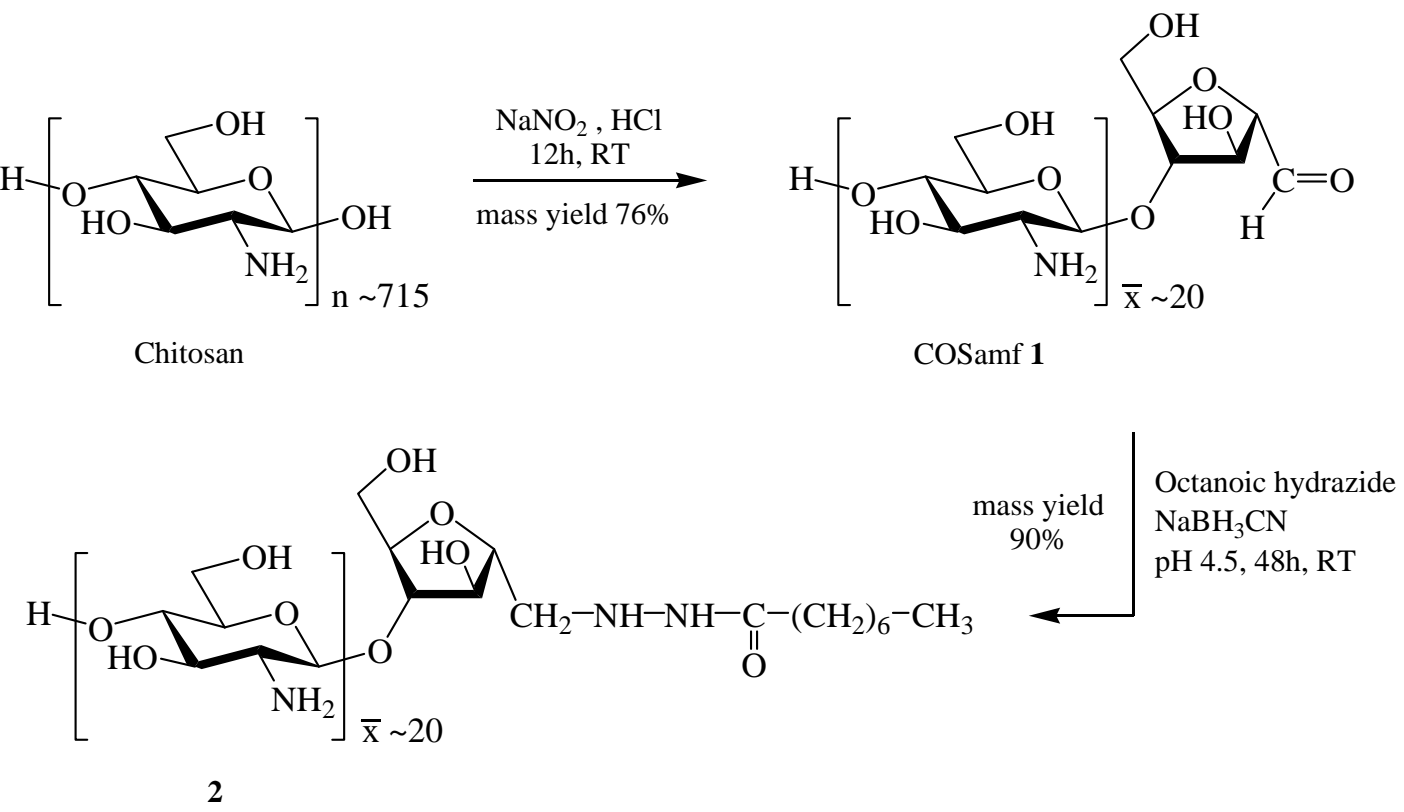

Scheme 1. Synthesis of octanoic acid-linked chitooligosaccharide-2,5-anhydro-D-mannofuranose (2) from chitosan.

COSamf 1 was prepared by nitrous acid depolymerization of fully $\mathrm{N}$-deacetylated chitosan based on the method previously described by Tommeraas et al. [16]. Thus, the depolymerization of chitosan by sodium nitrite $\left(\mathrm{NaNO}_{2} ; \mathrm{GlcN} / \mathrm{NaNO}_{2}\right.$ molar ratio $\left.=10: 1\right)$ in aqueous acid solution at room temperature led to COSamf $\mathbf{1}$ in $76 \%$ mass yield after $12 \mathrm{~h}$ of reaction. The chemical structure of COSamf 1 was fully confirmed by NMR $\left({ }^{1} \mathrm{H}\right.$ and $\left.{ }^{13} \mathrm{C}\right)$ spectroscopy and MALDI-TOF mass spectrometry. It has been shown by MALDI-TOF analyses that COSamf $\mathbf{1}$ is composed of a mixture of oligomers with an average number of GlcN units $(\bar{x})$ into chains around 20 . The $\bar{x}$ value was determined by ${ }^{1} \mathrm{H}-\mathrm{NMR}$ from the relative peak intensities of $\mathrm{H}-4(\mathrm{amf})$ and $\mathrm{H}-2(\mathrm{GlcN})$ signals at 4.23 and $3.15 \mathrm{ppm}$, respectively, according to the formula (1):

$$
\overline{\mathrm{x}}=\frac{\mathrm{I}_{\mathrm{H}-2(\mathrm{GlcN})}}{\mathrm{I}_{\mathrm{H}-4(\mathrm{amf})}}
$$

The reductive amination of COSamf 1 with octanoic hydrazide in the presence of $\mathrm{NaBH}_{3} \mathrm{CN}$ was carried out at room temperature in ethanol/acetate buffer solution ( $\mathrm{pH} 4.5)$ for $48 \mathrm{~h}$, leading to the targeted octanoic hydrazide-linked COSamf 2 in excellent mass yield $(90 \%)$ after purification. The chemical structure of compound 2 was entirely characterized by ${ }^{1} \mathrm{H}-$ and ${ }^{13} \mathrm{C}-\mathrm{NMR}$ spectroscopies thanks to two-dimensional NMR analyses (COSY, HSQC and HMBC), pointing out the coupling reaction between the aldehyde function of COSamf $\mathbf{1}$ and the amine group of the hydrazide residue. Thus, the presence of the corresponding $\mathrm{CH}_{2}-\mathrm{N}$ covalent linkage was displayed at $\delta 3.37 \mathrm{ppm}$ for the methylene protons and at $52.3 \mathrm{ppm}$ for the methylene carbon in ${ }^{1} \mathrm{H}$ - and ${ }^{13} \mathrm{C}-\mathrm{NMR}$ spectra, respectively. As confirmed by MALDI-TOF mass spectrometry (see supplementary materials for more details), octanoic hydrazide-linked COSamf $\mathbf{2}$ is composed of a mixture of oligomers with a $\bar{x}$ value determined by ${ }^{1} \mathrm{H}-\mathrm{NMR}$ equal to around 20 . This result confirms that reductive amination conditions used in this study did not affect the GlcN backbone of the starting COSamf $\mathbf{1}(\overline{\mathrm{x}} \sim 20)$.

\section{Materials and Methods}

\subsection{Materials and Analytical Methods}

Commercial chitosan (batch 244/020208; degree of $N$-acetylation: DA $<1 \%, \overline{\mathbf{M}_{\mathbf{w}}}=270 \mathrm{~kg} / \mathrm{mol}$; $\overline{\mathbf{M}_{\mathbf{n}}}=115 \mathrm{~kg} / \mathrm{mol}$, dispersity: $Đ=2.3$ ) was supplied by Mahtani Chitosan Ltd. (Veraval, India). 
Sodium nitrite (assay $>99 \%$ ), octanoic hydrazide (assay $>80 \%$ ), deuterium oxide $\left(\mathrm{D}_{2} \mathrm{O}\right.$, assay $>99.96 \%$ atom D), all others chemicals and solvents were provided by Sigma-Aldrich (Saint-Quentin Fallavier, France). ${ }^{1} \mathrm{H}-{ }^{13} \mathrm{C}-\mathrm{NMR}$ and MALDI-TOF (2,5-dihydroxybenzoic acid matrix) analyses were performed according to procedures previously described in the literature [14].

\subsection{Synthesis of COSamf $\mathbf{1}$}

Chitosan (2.1g, 13 mmole of GlcN unit) was solubilized in $100 \mathrm{~mL}$ of water by addition of $1.2 \mathrm{~mL} \mathrm{HCl}(37 \% w / w)$. A freshly prepared $5 \mathrm{~mL}$ aqueous solution of $\mathrm{NaNO}_{2}(90 \mathrm{mg}, 0.13 \mathrm{mmol}$ for $\mathrm{GlcN} / \mathrm{NaNO}_{2}$ molar ratio = 10:1) was added and the reaction was allowed to proceed for $12 \mathrm{~h}$ at room temperature. Oligomers were precipitated by addition of ammonium hydroxide solution $(28 \% w / w)$ to $\mathrm{pH} \sim 9$, washed several times with distilled water until neutral $\mathrm{pH}$, then freeze-dried leading to COSamf 1 (1.6 g, 76\% mass yield) as a white powder. ${ }^{1} \mathrm{H}-\mathrm{NMR}\left(500 \mathrm{MHz}, \mathrm{D}_{2} \mathrm{O}\right): \delta(\mathrm{ppm})$ $5.10(\mathrm{~d}, J=5.4 \mathrm{~Hz}, 1 \mathrm{H}, \mathrm{H}-1 \mathrm{amf}), 4.90-4.70(\mathrm{~m}, 22 \mathrm{H}, \mathrm{H}-1 \mathrm{GlcN}), 4.45(\mathrm{t}, J=4.9 \mathrm{~Hz}, 1 \mathrm{H}, \mathrm{H}-3 \mathrm{amf}), 4.23$ $(\mathrm{t}, J=4.9 \mathrm{~Hz}, 1 \mathrm{H}, \mathrm{H}-4 \mathrm{amf}), 4.13$ (m, 1H, H-5 amf), 4.05-3.45 (m, 113H, H-2 and H-6 amf, H-3 to H-6 GlcN), 3.20-3.10 (m, 22H, H-2 GlcN). ${ }^{13} \mathrm{C}-\mathrm{NMR}\left(125 \mathrm{MHz}, \mathrm{D}_{2} \mathrm{O}\right): \delta(\mathrm{ppm}) 99.2$ (C-1' GlcN), 98.6 (C-1 GlcN), 89.8 (C-1 amf), 86.5 (C-4 amf), 85.6 (C-2 amf), 82.6 (C-5 amf), 77.2 (C-3 amf), 77.0 (C-4 GlcN), 76.9 (C-5' GlcN), 75.3 (C-5 GlcN), 72.5 (C-3' GlcN), $71.0(\mathrm{C}-3 \mathrm{GlcN}), 70.2\left(\mathrm{C}-4^{\prime} \mathrm{GlcN}\right), 61.4$ (C-6 amf), 60.9 (C-6' GlcN), 60.6 (C-6 GlcN), $56.5(\mathrm{C}-2 \mathrm{GlcN}), 56.2\left(\mathrm{C}-2^{\prime} \mathrm{GlcN}\right)$. Note that $\mathrm{C}^{\prime}$ represents the carbon atoms of the GlcN unit linked to the amf unit. MALDI-TOF MS (positive reflectron mode): major peak at $m / z 1473.9$ assigned to $\mathrm{HO}-(\mathrm{GlcN})_{8}$-amf $\left(m / z\right.$ monoisotopic calcd for $\left[\mathrm{C}_{54} \mathrm{H}_{98} \mathrm{O}_{37} \mathrm{~N}_{8} \mathrm{Na}\right]^{+}=$ $1473.6 \mathrm{~m} / \mathrm{z})$.

\subsection{Synthesis of Octanoic Hydrazide-Linked Chitooligosaccharide-2,5-Anhydro-D-Mannofuranose 2}

COSamf 1 (1g, $0.3 \mathrm{mmol}$ of amf unit) was dissolved into $20 \mathrm{~mL}$ aqueous ammonium acetate buffer ( $0.2 \mathrm{M}, \mathrm{pH} 4.5) .600 \mathrm{mg}$ of octanoic hydrazide $(3.0 \mathrm{mmol}, 10$ eq./amf unit) solubilized in $20 \mathrm{~mL}$ of ethanol were added and the mixture was stirred for one day at room temperature. Sodium cyanoborohydride $(190 \mathrm{mg}, 3.0 \mathrm{mmol})$ was then added and the mixture was stirred for one day at room temperature. Oligomers were precipitated by addition of ammonium hydroxide solution $(28 \% w / w)$ to $\mathrm{pH} \sim 9$, washed several times with distilled water until neutral $\mathrm{pH}$, then freeze-dried leading to the compound $2\left(0.9 \mathrm{~g}, 90 \%\right.$ mass yield) as white powder. ${ }^{1} \mathrm{H}-\mathrm{NMR}\left(500 \mathrm{MHz}, \mathrm{D}_{2} \mathrm{O}\right): \delta(\mathrm{ppm}) 4.91$ (m, 20H, H-1 GlcN), 4.32 (m, 1H, H-3 amf), 4.25-4.10 (m, 3H, H-2 amf, H-4 amf, H-5 amf), 4.05-3.50 (m, 122H, H-3 to H-6 GlcN, H-6 amf), 3.37 (m, 2H, CH $\left.{ }_{2} \mathrm{~N}\right), 3.25-3.10(\mathrm{~m}, 20 \mathrm{H}, \mathrm{H}-2 \mathrm{GlcN}), 2.30(\mathrm{~m}, 2 \mathrm{H}$, $\left.\mathrm{CH}_{2} \mathrm{CO}\right), 1.60\left(\mathrm{~m}, 2 \mathrm{H}, \mathrm{CH}_{2}\right), 1.35-1.20\left(\mathrm{~m}, 8 \mathrm{H}, 4 \times \mathrm{CH}_{2}\right), 0.85\left(\mathrm{~m}, 3 \mathrm{H}, \mathrm{CH}_{3}\right) .{ }^{13} \mathrm{C}-\mathrm{NMR}\left(125 \mathrm{MHz}, \mathrm{D}_{2} \mathrm{O}\right)$ : $\delta(\mathrm{ppm}), 175.5(\mathrm{CO}), 99.3\left(\mathrm{C}-1^{\prime} \mathrm{GlcN}\right), 98.2(\mathrm{C}-1 \mathrm{GlcN}), 86.6$ (C-4 amf), 82.9 (C-5 amf), 79.3 (C-2 amf), 78.0 (C-3 amf), 77.1 (C-5' GlcN), 77.0 (C-4 GlcN), 75.4 (C-5 GlcN), $72.4\left(\mathrm{C}-3^{\prime} \mathrm{GlcN}\right), 70.7$ (C-3 GlcN), 70.3 (C-4' GlcN), 61.9 (C-6 amf), 61.0 (C-6' GlcN), 60.7 (C-6 GlcN), 56.5 (C-2 GlcN), 56.2 (C-2' GlcN), 52.3 $\left(\mathrm{CH}_{2} \mathrm{~N}\right), 34.0,31.6,28.7,28.6,25.3,22.6\left(6 \times \mathrm{CH}_{2}\right), 14.1\left(\mathrm{CH}_{3}\right)$. Note that $\mathrm{C}^{\prime}$ represents carbon atoms of the GlcN unit linked to the amf unit. MALDI-TOF MS (positive reflectron mode): major peak at $1777.2 \mathrm{~m} / z$ assigned to $\mathrm{HO}-(\mathrm{GlcN}))_{9}-\mathrm{C}_{14} \mathrm{H}_{28} \mathrm{O}_{5} \mathrm{~N}_{2}\left(\mathrm{~m} / z\right.$ monoisotopic calcd for $\left[\mathrm{C}_{68} \mathrm{H}_{127} \mathrm{O}_{41} \mathrm{~N}_{11} \mathrm{Na}\right]^{+}=$ $1776.8 \mathrm{~m} / \mathrm{z})$.

Supplementary Materials: Supplementary materials can be accessed at: http://www.mdpi.com/1422-8599/ 2016/3/M904.

Acknowledgments: The authors thank Catherine Ladavière (IMP, CNRS) and Bernard Fenet (CCRMN, Université Lyon 1) for their helpful assistance and discussions in MALDI-TOF mass spectrometry and NMR spectroscopy analyses, respectively.

Author Contributions: S.T. conceived and designed the experiments; A.M. performed the experiments; A.M. and S.T. analyzed the data; S.T. wrote the paper.

Conflicts of Interest: The authors declare no conflict of interest. 


\section{References}

1. Kurita, K. Chitin and chitosan: Functional biopolymers from marine crustaceans. Mar. Biotechnol. 2006, 8 , 203-226. [CrossRef] [PubMed]

2. Dash, M.; Chiellini, F.; Ottenbrite, R.M.; Chiellini, E. Chitosan: A versatile semi-synthetic polymer in biomedical applications. Prog. Polym. Sci. 2011, 36, 981-1014. [CrossRef]

3. Younes, I.; Rinaudo, M. Chitin and chitosan preparation from marine sources. Structure, properties and applications. Mar. Drugs 2015, 13, 1133-1174. [CrossRef] [PubMed]

4. Hamed, I.; Ozogul, F.; Regenstein, J.M. Industrial applications of crustacean by-products (chitin, chitosan and chitooligosaccharides): A review. Trends Food Sci. Technol. 2016, 48, 40-50. [CrossRef]

5. Mourya, V.K.; Inamdar, N.N.; Choudhari, Y.M. Chitooligosaccharides: Synthesis, characterization and applications. Polym. Sci. Ser. A 2011, 53, 583-612. [CrossRef]

6. Kim, S.-K.; Rajapakse, N. Enzymatic production and biological activities of chitosan oligosaccharides (COS): A review. Carbohydr. Polym. 2005, 62, 357-368. [CrossRef]

7. Aam, B.B.; Heggset, E.B.; Norberg, A.L.; Sørlie, M.; Vårum, K.M.; Eijsink, V.G.H. Production of chitooligosaccharides and their potential applications in medicine. Mar. Drugs 2010, 8, 1482-1517. [CrossRef] [PubMed]

8. Xia, W.; Liu, P.; Zhang, J.; Chen, J. Biological activities of chitosan and chitooligosaccharides. Food Hydrocoll. 2011, 25, 170-179. [CrossRef]

9. Hussain, I.; Singh, T.; Chittenden, C. Preparation of chitosan oligomers and characterization: Their antifungal activities and decay resistance. Holzforschung 2012, 66, 119-125. [CrossRef]

10. Das, S.N.; Madhuprakasha, J.; Sarma, P.V.S.R.N.; Purushotham, P.; Suma, K.; Manjeet, K.; Rambabu, S.; el Gueddari, N.E.; Moerschbacher, B.M.; Podile, A.R. Biotechnological approaches for field applications of chitooligosaccharides (COS) to induce innate immunity in plants. Crit. Rev. Biotechnol. 2015, 35, $29-43$. [CrossRef] [PubMed]

11. Lodhi, G.; Kim, Y.-S.; Hwang, J.-W.; Kim, S.-K.; Jeon, Y.-J.; Je, J.-Y.; Ahn, C.-B.; Moon, S.-H.; Jeon, B.-T.; Park, P.-J. Chitooligosaccharide and its derivatives: Preparation and biological applications. BioMed. Res. Int. 2014. [CrossRef] [PubMed]

12. Rasmussen, M.O.; Hogg, B.; Bono, J.-J.; Samain, E.; Driguez, H. New access to lipo-chitooligosaccharides nodulations factors. Org. Biomol. Chem. 2004, 2, 1908-1910. [CrossRef] [PubMed]

13. Illy, N.; Robitzer, M.; Auvergne, R.; Caillol, S.; David, G.; Boutevin, B. Synthesis of water-soluble allyl-functionalized oligochitosan and its modification by thiol-ene addition in water. J. Polym. Sci. Part A Polym. Chem. 2014, 52, 39-48. [CrossRef]

14. Trombotto, S.; Ladavière, C.; Delolme, F.; Domard, A. Chemical preparation and structural characterization of a homogeneous series of chitin/chitosan oligomers. Biomacromolecules 2008, 9, 1731-1738. [CrossRef] [PubMed]

15. Abla, M.; Marmuse, L.; Delolme, F.; Vors, J.-P.; Ladavière, C.; Trombotto, S. Access to tetra- $N$-acetylchitopentaose by chemical $N$-acetylation of glucosamine pentamer. Carbohydr. Polym. 2013, 98, 770-777. [CrossRef] [PubMed]

16. Tommeraas, K.; Varum, K.M.; Christensen, B.E.; Smidsrod, O. Preparation and characterization of oligosaccharides produced by nitrous acid depolymerization of chitosans. Carbohydr. Res. 2001, 333, 137-144. [CrossRef]

(C) 2016 by the authors; licensee MDPI, Basel, Switzerland. This article is an open access article distributed under the terms and conditions of the Creative Commons Attribution (CC-BY) license (http://creativecommons.org/licenses/by/4.0/). 